\title{
Pasado y presente: los jesuitas de la misión Nahuel Huapi (1670-1674 y 1704-1717) y la devoción Mariana.
}

Past and present: the jesuits of the Nahuel Huapi mision

(1670-1674 and 1704-1717) and the Marian devotion

María Andrea Nicoletti ${ }^{*}$

\section{Resumen}

A orillas del lago Nahuel Huapi, los jesuitas de la Araucanía fundaron una misión como prolongación de las misiones chilotas para ganar tierras y súbditos al otro lado de la cordillera. Lo hicieron en dos etapas: 1670-1674 y 1703 -1717. Presentaremos en este trabajo dos cuestiones significativas que se proyectan en tensión hacia el presente: el martirio de los jesuitas del Nahuel Huapi y la devoción de la Virgen María. El martirio del P. Mascardi transformó en mártires a sus sucesores de acuerdo a las actuales narrativas contradiciendo a las fuentes. La Misión bajo la advocación de la Virgen resultó clave en relación a su patronazgo, sus títulos y su iconografía. La supervivencia de su imagen en el incendio que destruyó la misión y su "supuesto hallazgo" en la actualidad, la convirtieron en un emblema de "cristiandad colonial" regada con la "sangre del martirio", que remite al pasado jesuita colonial.

\section{Palabras clave:}

Jesuitas - Nahuel Huapi - misión - Virgen María - indígenas.

\section{Abstract}

Near Nahuel Huapi's lake, the Jesuits of the Araucanía founded a mission as an extension of the Chiloé missions, to gain lands and subjects on the other side of the mountain. They did it in two stages: 1670-1674 and 1703-1717. In this work, we will present two significant issues that projected into the present: the martyrdom of the Jesuits of the Nahuel Huapi and the devotion of the Virgin Mary. The martyrdom of P.

\footnotetext{
* Instituto de Investigaciones en Diversidad Cultural y Procesos de Cambio/CONICET/Universidad Nacional de Río Negro y Grupo de Estudios sobre Religiosidad y Evangelización (GERE), Facultad de Filosofía y Letras/Universidad de Buenos Aires).
} 
Mascardi transformed into martyrs their successors, according the present narratives contradicting the original documents. The mission under the advocation of the Virgin was the key in relation to the patronage, the titles and the iconography. The survival of her image in the fire that destroyed the mission and her "discovery" in the present, developed into an emblem of "colonial Christianity" replete with the "blood of martyrdom", which forwards the last colonial Jesuit.

\section{Key-Words:}

Jesuits - Nahuel Huapi - mission - Virgin Mary - indigenous.

\section{Recibido: 9 de junio de 2014}

Evaluado: 25 de junio de 2014 


\section{Los jesuitas del Nahuel Huapi y la misión a los “gentiles” transcordilleranos}

Durante la etapa colonial, en pleno proceso de expansión hacia la Araucanía, los jesuitas del Reino de Chile establecidos en la isla de Chiloé, extendieron hacia el otro lado de la cordillera su proyecto evangelizador con la fundación de la misión del Nahuel Huapi (1670-1674 y 1703-1717) entre los indígenas puelches y poyas. Este fue el centro del que partieron los jesuitas que misionaron en el Nahuel Huapi, una "puerta que patente, se descubrían muchas regiones, aunque parece que todavía no están sazonadas por la cosecha" ${ }^{1}$.

La misión del Nahuel Huapi se encontraba dentro del proyecto de un conjunto de misiones nuevas fundadas entre 1692 y 1695: Colue, Cule, Maquegua, Boroa, Imperial y Repocura, con las que la Corona se aseguraba tierras ocupadas sin enfrentamientos que desgastaran al ejército español y con un gasto mínimo².

El contexto histórico colonial misionero de la Araucanía durante los siglos XVII y XVIII se enmarcó en un proceso social y económico configurado por una economía emergente y una tenaz resistencia indígena, que tras el alzamiento de 1598, se desplazó a la isla de Chiloé, comunicándose directamente con el Nahuel Huapi. Para la Corona española, la fundación de una misión transcordillerana era un enclave de penetración hacia el Estrecho y un resguardo contra las potencias europeas enemigas de España. Para los jesuitas, el "pacto colonial" entre la monarquía y la Iglesia, les permitía expandir su propia economía y proyectar sus misiones como únicos agentes e interlocutores con los "indios rebeldes".

Desde el Reino de Chile, el área del Nahuel Huapi, despertó particular interés desde el siglo XVI, para someter a sus habitantes originarios mediante malocas "por ser territorio adyacente al camino existente entre Villarrica y Buenos Aires" ${ }^{3}$. Las distintas entradas enviadas por los gobernadores del Reino de Chile entre los siglos XVI y XVII, "hace suponer que se avanzaba sobre terreno conocido, siguiendo tal vez el mismo derrotero de los grupos maloqueros chilotes" ${ }^{4}$. La ruta seguida por el capitán Fernández en 1621, o camino de las lagunas, dejó definitivamente abierto el paso por tierra y por agua en dalcas desarmables ${ }^{5}$. "Desde el fuerte de Calbuco por mar hasta Ralún, pasando de allí al lago Purailla y luego por tierra hasta el lago de Todos los Santos, para volver a armar las dalcas, cruzarlo e ingresar al rio Peulla remontándose a Nahuelhuapi, cubriendo 33 leguas desde el lugar de origen" (...) por el actual paso de los Raulies o quizás por el de Pérez Rosales, luego la navegación por Nahuelhuapi hasta su desagüe en el río Limay, para seguir por el margen derecho de ese río y después regresar deshaciendo lo andado" ${ }^{6}$. Entre 1651 y 1653 el P. Diego de Rosales ${ }^{7}$ penetró en la zona en una incursión apostólica en el Volcán Lanín primero y el Nahuel Huapi después.

\footnotetext{
${ }^{1}$ Olivares, 1874: 390.

${ }^{2}$ Enrich, 1891: 51.

${ }^{3}$ Urbina,2008: 9.

${ }^{4}$ Ibíd: 11.

${ }^{5}$ Albornoz y Hajduk, 2001.

${ }^{6}$ Urbina, 2008: 10.

${ }^{7}$ Page, 2012: 347-349.
} 
Igual que el caso de Mascardi, Rosales fue uno de los misioneros cuyo propósito fue restituir indígenas tomados prisioneros por las malocas españolas.

Podemos establecer en la Misión del Nahuel Huapi dos etapas: El período del P. Mascardi (1670-74) ${ }^{8}$ y el que inicia el Padre Philliphi van den Meeren o Felipe de la Laguna en 1703, que terminó con el incendio de $1717^{9}$.

La misión de Mascardi fue una incursión apostólica para restituir a un grupo de indígenas poyas del Nahuel Huapi, esclavizados en Chiloé y un reconocimiento del territorio a través de cuatro viajes hacia el Estrecho en busca de la legendaria ciudad de los Césares. El padre Nicolás Mascardi actuó entre 1670 y principios de 1674, adoctrinando y bautizando a los indígenas Poyas "identificados con los cazadores recolectores ecuestres asentados en el ámbito de estepa al este del lago"10. Los caciques ofrecieron a Mascardi que fijara su sede entre ellos, pero el jesuita eligió una de las márgenes del lago, en un lugar céntrico, porque:

"podría más fácilmente asistir a las naciones establecidas en las faldas y en los dilatados valles de los Andes y a las que moraban en las cordilleras del naciente, en los espaciosos campos del Norte y en las extensas campañas del sur hasta el Estrecho de Magallanes" $"$.

"No se descarta pudo haber dispuesto de un residencia fija en vecindad de la península Huemul” 12 .

Tras el asesinato de Mascardi, lejos del Nahuel Huapi, en territorio santacruceño, "no se interrumpieron los contactos entre los indígenas de las inmediaciones del lago y la provincia de Chiloé” y "tampoco se detuvo el comercio entre Nahuel Huapi y Chiloé”. Incluso, “aunque la misión se fundó formalmente en 1703, los padres se habrían establecido en Nahuelhuapi desde antes, porque en julio de 1702, el presidente de Chile decía que ya tenía dos años de vida"13. La misión se fundó definitivamente en 1703, treinta años después de Mascardi, "excepto el paréntesis de Calihuaca” $^{14}$, con la llegada de Felipe de la Laguna ${ }^{15}$ y según los españoles y padres jesuitas a petición de los mismos poyas ${ }^{16}$. Según el jesuita Enrich un cacique "recordaba todavía después de treinta años, las oraciones y doctrinas que había aprendido del $\mathrm{P}$. Mascardi"17, argumento utilizado para reforzar el pedido.

De la Laguna invitó a los caciques "a que vivieran conmigo y fundaran allí una pequeña población para que pudieran, con todos los suyos, tomar parte más fácil, en el

\footnotetext{
${ }^{8}$ Ibíd: 350-57.

${ }^{9}$ Ibíd: 356-64.

${ }^{10}$ Hajduk y Braicovich, 2012: 7.

${ }^{11}$ Mascardi, 1670: 740.

${ }^{12}$ Hajduk y Braicovich, 2012: 7.

${ }^{13}$ Urbina, 2008: 15 y 18.

${ }^{14}$ Urbina, 2007: 356.

${ }^{15}$ Enrich, 1891: 54.

${ }^{16}$ Seguramente para obtener protección contra la agresión de los puelche.

${ }^{17}$ Enrich 1891: 54.
} 
catecismo y en la oración"18 ${ }^{18}$ Levantó primero una choza y altar para la celebración de la misa, que a la vuelta de uno de sus viajes se convirtió en una Iglesia ${ }^{19}$. Sobre el sitio de fundación, que De la Laguna no menciona ${ }^{20}$, hay divergencias de interpretación, como también en cuanto a los caminos de acceso $^{21}$ y las jurisdicciones ${ }^{22}$. De todos

\footnotetext{
${ }^{18}$ De la Laguna, 1704: 233.
}

${ }^{19}$ Ibíd: 233-34.

20 “Al igual que la fundación de Mascardi, no es posible precisar el punto exacto donde se levantó la misión del Nahuel Huapi. Urbina cita a García Gorrono que la sitúa en la península de San Pedro, orilla sur del lago pero que después fue trasladada a un punto más confortante, quizá el llamado Chuenque”. Urbina 2008:19 cit. García Gorrono, Benjamín, El camino de Vuriloche, RChHG, 103, 104, 108 y 109, Santiago, 1943-46. Otro reconocimiento in situ fue el de Fray Francisco Menéndez. En el estudio crítico de sus viajes realizado por Francisco Fonk, entiende que la misión se estableció en la costa occidental del lago (Fonk, 1896: 52). Sobre la reconstrucción de la misión por parte del jesuita Manuel del Hoyo, tras el incendio, dice Fonck que es posible que haya sido el sitio donde se encontraron restos de ladrillos en Península San Pedro, coincidente con lo que afirmaba Menéndez (Fonck, 1896: 76). Milcíades Vignati reinterpreta esta fuente en 1944 y la ubica en Península Huemul por un enterramiento allí hallado. De acuerdo a los últimos estudios arqueológicos realizados en relación a la localización de la Misión, Adam Hajduk, coincide con Vignatti mencionando que "se destaca el hallazgo de un cementerio con enterratorios que evidencian rasgos indígenas y cristianos, en la Península Huemul” (Albornoz y Hajduk 1991: 11). En su último estudio, aun inédito, Hajduk y Braicovich afirman que "respecto al lugar de emplazamiento de esta misión los mapas debidos a los jesuitas Falkner y Cardiel la sitúan sobre la margen norte del lago. Según nuestra interpretación de los escritos de Fray Francisco Menéndez, en los cuales describe los viajes que realizó al Nahuel Huapi hacia fines del siglo XVIII, se desprende que los restos de la Misión que él pudo observar entonces, se hallarían en inmediaciones del actual Puerto Venado. Cabe mencionar aquí que en el actual Puerto Huemul en 1931, don Carlos Ortiz Basualdo localizó y excavó un cementerio indígena de características particulares. Milcíades Alejo Vignatti publicó un trabajo en relación, indicando que varios de los inhumados seguían en su disposición un patrón cristiano; estas características más el análisis de restos arqueológicos recuperados y de las fuentes históricas referidas a los jesuitas, le hace plantear a Puerto Huemul como lugar donde se habría emplazado la Misión. Vignatti, 1944. La disyuntiva que se plantea si la Misión se emplazó en Puerto Huemul o bien en Puerto Venado no está aún resuelta. El hecho de que en Puerto Huemul haya aparecido un cementerio indígena que denota influencias cristiana, no indica que necesariamente allí habríase localizado la Misión. No se descarta que ambos puertos pudieron ser ocupados por los padres jesuitas en forma complementaria” (Hajduk y Braicovich, 2012: 7).

${ }^{21}$ En su “Carta Relación” Nicolás Mascardi dice que vino: “a pie desde ese mar y pasar la cordillera y venir descalzo por el pedregal y muchas vueltas del río de Peulla (...), luego me embarque al otro lado de la laguna de Todos los Santos (...), luego que llegué a la cumbre de cordillera y empecé a divisar nuevas cumbres y campañas de esta banda, planté y levanté una cruz” (Mascardi, 1670: 118). En cuanto a los caminos seguidos a partir de Felipe de la Laguna y el descubrimiento del paso de los Vuriloche ver: Urbina, 2008 y Albornoz y Hajduk, 2001. Urbina distingue dos caminos: uno terrestre y otro lacustre. El terrestre "mientras estuvo transitable fue mérito de Guillelmo, asegurando más expedita comunicación con Chiloé, donde estaba el colegio de la Compañía y donde llegaban los suministros en casos de urgencia, los operarios de reemplazo y la mano de obra necesaria. El camino que se seguía entre Nahuelhuapi, Concepción y Santiago era bajando en latitud por los faldeos orientales de la cordillera, pasando por tierras pehuenches. Desde Nahuel Huapi a Valdivia las fuentes mencionan los parajes de Colihuaca y más al norte el de Rucachoroi, para luego cruzar la cordillera por el paso de Villarica, como lo hicieron los Padres Guillelmo, de la Laguna y llegar a la plaza fuerte tras ocho días de viaje. Hacia Concepción, la cordillera se cruzaba más al norte, por algún boquete en el nacimiento del rio Bío Bío y se atravesaba de este a oeste hasta llegar a esa ciudad. En ambos casos se transitaba por tierras de indios de guerra a los que había que agasajar para lograr la necesaria licencia de paso” (Urbina, 2008: 23). Los últimos estudios arqueológicos de Hajduk $\mathrm{y}$, permitieron por el material encontrado en un sitio arqueológico en el ámbito de la península de Llao Llao, hallar una posible posta intermedia "empleada por los jesuitas en su tránsito lacustre entre Brazo Blest y el asentamiento de su misión en la costa noreste del lago Nahuel Huapi” (Hajduk y Albornoz, 2001: 7). 
modos, por la modalidad de evangelización desplegada en Chiloé por la Compañía de Jesús, coincidimos con Hajduk y Braicovich, que puede haberse tratado de una misión en jalones hasta la construcción definitiva de la Iglesia y la reducción ${ }^{23}$.

Cuando el Padre Guillelmo en reemplazo del Padre Sesa, llegó al Nahuel Huapi en 1704, De la Laguna aprovechó para viajar a Chiloé y encarar definitivamente la construcción de la "nueva Misión de la Compañía de Jesús, en Sud América, en Nahuel Huapi”,24 (Fig. 1).

Logró la construcción de una casa en tres semanas, una Iglesia pequeña y también en su entorno, "algunas casas para habitación de los caciques" ${ }^{25}$. Una vez afianzada su construcción, Felipe de la Laguna volvió a viajar a Valdivia en busca de "apoyo y fomento, no tanto material, como moral de la naciente misión" ${ }^{26}$.

A pesar de los problemas, enfrentamientos intertribales, la misión siguió creciendo con la construcción de una nueva Iglesia ${ }^{27}$. En una de sus incursiones apostólicas a tierras pehuenches, cuando se dirigía a Concepción, de la Laguna fue envenenado en Calihuaca por un cacique, según el relato del jesuita Olivares ${ }^{28}$. Su compañero Juan José Guillelmo se hizo cargo de la misión, “construyóse también una nueva Iglesia en la misión (...) por no caber en la primitiva la mucha gente que concurría" 29 , tratando de lograr una suerte de autoabastecimiento con sembradíos y ganado "que compró de los indios del norte" ${ }^{30}$ y buscando la apertura de un antiguo paso que permitiera una comunicación más intensa con el Reino de Chile ${ }^{31}$.

\footnotetext{
${ }^{22}$ En acuerdo entre la Junta general de Misiones y la Real Hacienda para su sostenimiento, era enviar dos jesuitas misioneros para "los indios que residen en las reducciones de Nahuelhuapi, que está en la provincia de Chiloé, es decir, era dependiente temporal y espiritualmente de Chiloé, pero económicamente del situado de Valdivia, que incluía el sínodo. De todas formas tanto Valdivia como Chiloé recibían el situado que pagaba el rey por medio de las cajas reales del Virreinato. Gabriel Guarda sostiene que la misión era dependiente de la jurisdicción de Valdivia. Esto supondría que el límite oriente de la plaza se modificó prolongándose hasta el área del lago para abarcar la misión. Para Vázquez de Acuña, la misión siempre perteneció espiritualmente al Colegio de Castro y jurisdiccionalmente al gobierno de Chiloé, con independencia de la vía por donde llegaba el sínodo. Coincidimos con esta conclusión (Urbina, 2008:17).

23 Por otra parte la mención por parte de Fray Menéndez de la existencia de un lugar en donde antiguamente hubo Misión en la costa este del lago, cerca del Cerro Leones, plantea la posibilidad cierta que en el ámbito del lago pudo haber una serie de sitios satélites secundarios relacionados a la actividad misionera. Tal sería el caso del sitio "Cancha de Pelota" que uno de nosotros a identificado no lejos de Llao Llao .(Hajduk, 1991:1-24). Se trata de un sitio arqueológico de contacto hispano indígena, al cual se interpreta como correspondiente a una posta intermedia de los jesuitas en sus travesías lacustres entre el fondo del Brazo Blest y la Misión situada en la margen norte del lago. Es de suponer que condiciones climáticas adversas, habrían obligado frecuentemente a realizar esperas en procura de mejores condiciones para realizar el cruce del lago” (Hajduk y Braicovich, 2012: 7).
}

${ }^{24}$ de la Laguna, 1704: 231.

${ }^{25}$ Enrich, 1891: 58.

${ }^{26}$ de la Laguna, 1704: 59.

${ }^{27}$ Enrich, 1891: 73.

${ }^{28}$ Olivares, 1874, VII: 521-522.

${ }^{29}$ Enrich, 1891: 73.

${ }^{30}$ Ibíd.: 73.

${ }^{31}$ Enrich, 1891: 74.

46 María Andrea Nicoletti. Pasado y presente: los jesuitas de la misión Nahuel Huapi... : 41-64 


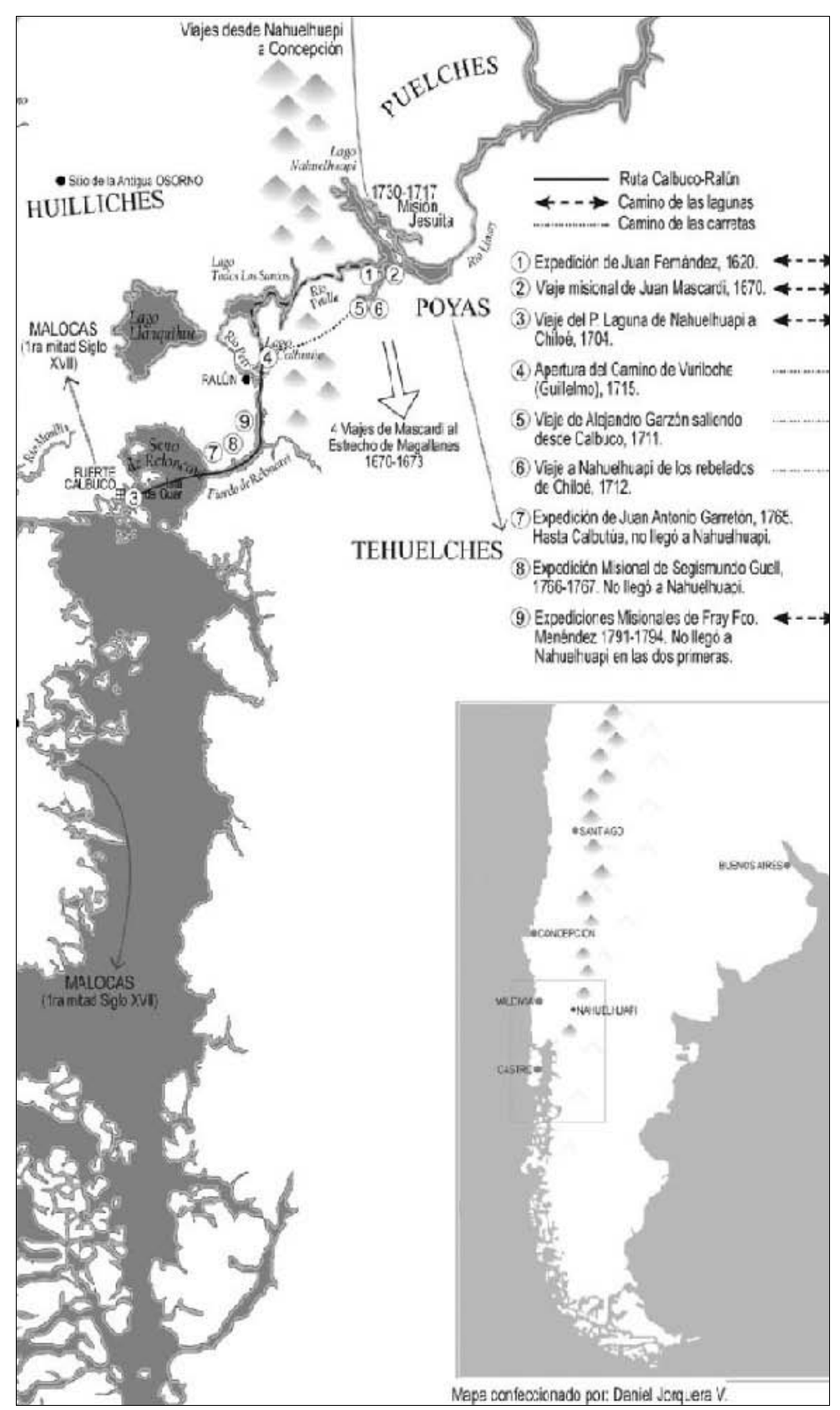

Fig. 1. Nahuel Huapi en los siglos XVII y XVIII. Fuente: Urbina, María Ximena. (2008), "La frustrada misión estratégica de Nahuelhuapi, un punto en la inmensidad de la Patagonia”. Magallania, Vol. 36, $\mathrm{N}^{\circ}$ 1, pp. 5-30. http://www.scielo.cl/pdf/magallania/v36n1/art01.pdf. p.7. Confección del Mapa: Daniel Jorquera $\mathrm{V}$.

Su crecimiento se vio truncado en primer lugar por el abandono de la misión por parte de los caciques al comenzar la veranada y por la desconfianza de los indígenas al descubrir el padre Guillelmo el paso cordillerano de los Vuriloches en 1709, que mantenían en secreto ${ }^{32}$. Según la crónica, los puelche incendiaron la misión donde todo se perdió, menos la imagen de una Virgen y el P. Guillelmo salvó su vida.

${ }^{32}$ Olivares, 1874, VII: 532. 
A pesar del incendio los jesuitas insistieron nuevamente con la misión del Nahuel Huapi y el P. Manuel del Hoyo fue allí en 1712 y estuvo dos años reconstruyéndola. Hacia 1914 del Hoyo volvió a Castro y asumió la misión nuevamente Guillelmo abriendo el paso de los Vuriloche. Según el testimonio de Olivares, Guillelmo fue envenenado en $1716^{33}$, probablemente a causa de la apertura de ese paso. A la muerte de Guillelmo se enviaron desde el colegio de Castro a los padres José Portel y Francisco Elguea, pero por enfermarse Portel solo viajó Elguea en compañía de un joven inglés quienes posteriormente perecieron en el incendio de la misión. Quedó a cargo de la reconstrucción de la misión el padre Elguea, hasta tanto se nombraba provincial. El padre Elguea llegó en 1717 y volvió a proveer de ganado a la misión reconstruida, pero fue asesinado al negarse a darles ganado a los indígenas y la misión fue saqueada e incendiada en $1717^{34}$.

"De Chiloé fueron a Nahuelhuapi algunos españoles, con el P. Arnaldo Yaspers (...). El P. Yaspers vio con dolor los pocos restos de la casa e Iglesia, que el fuego no había consumido, entre los cuales halló el cuerpo quemado del P. Elguea"35. En este segundo incendio en el que murió el P. Elguea las fuentes mencionan una imagen "de la virjen (que) sacó uno con gran dificultad ${ }^{36}$. Francisco Enrich agrega que la imagen fue despojada "de sus ricos y vistosos vestidos, la dejaron cubierta con un cuero de caballo"37, "i la colocaron junto a la orilla del lago"38.

La búsqueda de esta imagen y su supuesto hallazgo forman parte de un nuevo relato sobre la misión Nahuel Huapi y la devoción mariana de Nuestra Señora de los Poyas y Puelches.

Dos aspectos distintivos se proyectan en tensión hacia el presente: los asesinatos de los jesuitas con la consideración de su martirio y la Virgen María, en relación a sus títulos, patronazgo e imágenes. Ambos elementos resignifican el discurso del presente reformulando el relato histórico, mediante la "memoria de los mártires de la misión Nahuel Huapi" y el hallazgo de la imagen de la Virgen que la patrocinó, tal como se advierte en los paneles el atrio de la Catedral de Bariloche.

\section{Los jesuitas del Nahuel Huapi, mártires por la Fe}

En las misiones jesuitas de la Araucanía, la resistencia indígena y la guerra con el ejército español hicieron que los misioneros depositaran su confianza: "a la protección divina; incluso se podría decir que buscando abiertamente el martirio, a juzgar por el tono que recorre las cartas personales, los informes de misiones y las propias annuas enviadas a Roma”39.

\footnotetext{
${ }^{33}$ Ibíd.: VII: 525.

${ }^{34}$ Enrich, 1891: 100.

${ }^{35}$ Enrich, 1891: 101.

${ }^{36}$ Olivares,1874: 525.

${ }^{37}$ Enrich,1891: 100.

${ }^{38}$ Fonk, 1896: 52.

${ }^{39}$ Valenzuela, 2011: 65.
} 
"Los jesuitas, en función de su ideal salvacionista, para sí y para los otros, ansiaban el martirio personal, la mayor gloria que un miembro de la Compañía de Jesús podría pedir" ${ }^{40}$ :

"y con todo perseveran constantes los jesuitas por el amor a Cristo, aunque llueven persecuciones de los demonios y mas de los hombres, y sin tener más fomento ni ayuda humana que testimonios y calumnias, fruto de la cruz de Cristo: padecen con gusto y están dispuestos a mayores trabajos hasta rendir la vida por su Criador, como la han dado tantos apostólicos de esta Compañía en las misiones $(\ldots)^{41}$.

Las crónicas jesuitas sobre la misión del Nahuel Huapi, relatan la muerte de Mascardi a manos de los indígenas en el territorios de Santa Cruz en 1674, los probables envenenamientos de los jesuitas Felipe de la Laguna en 1709 y de Juan Guillelmo en 1716; y la muerte a flechazos en el incendio de 1717 del P. Elguea ${ }^{42}$.

¿Cuáles fueron las circunstancias de las muertes de estos jesuitas?

En el caso de Mascardi, los indígenas le quitaron la vida a "pedradas o con las bolas enramadas que llaman laquis, a flechazos en odio a nuestra santa fe" ${ }^{\text {" } 3}$. Lo mismo le sucedió al P. Elguea, último misionero del Nahuel Huapi, al que "mataron cruelmente (...) con las mismas bolas y flechas (...). El cuerpo del padre Elguea se quemó con el fuego a la casa e iglesia i a todo lo edificado" ${ }^{44}$. Felipe de la Laguna y Juan José Guillelmo murieron por "indicios de que el achaque fue causado de algun oculto veneno" ${ }^{45}$.

La tensión que se advierte en los relatos del pasado (las crónicas de los jesuitas) con respecto a los discursos del presente, es la calificación de esas muertes como martirios. Los cronistas resaltan en las muertes de Elguea, Guillelmo y de la Laguna, la sospecha del asesinato intencional por el "odio a la fe"

Los cronistas se contradicen en su evaluación sobre el martirio. Mientras Olivares señala que Dios “no le concedió la corona del martirio” al P. de la Laguna, Enrich aclara que: "ignoramos los pormenores de su muerte, que muy bien podemos honrar con el nombre de martirio, habiendo sido el amor de Dios el motivo principal" 47 . Las sospechas se basaban en que el P. Felipe se puso en camino "bueno i sano" ${ }^{48}$ y "estaba acostumbrado a aquella bebida"49, descartando así la muerte natural o por intoxicación. Estas muertes estaban relacionadas para los cronistas con supuestas

\footnotetext{
${ }^{40}$ Deckmann Fleck, 2012: 5

${ }^{41}$ Covarrubias, 1718: 277-278.

42 Olivares, 1874 y Enrich, 1891.

${ }^{43}$ Olivares, 1874: 391.

${ }^{44}$ Ibíd, 200.

${ }^{45}$ Olivares, 1874 y Enrich, 1891.

${ }^{46}$ Enrich, 1891: 743.

${ }^{47}$ Ibíd, 744.

${ }^{48}$ Olivares, 1874: 192.

${ }^{49}$ Enrich, 1891: 63.
} 
venganzas $^{50}$. Felipe de la Laguna amonestó por su comportamiento a un/a machi ${ }^{51}$. El P. Elguea se negó a cederles a los indígenas las vacas que le pidieron y Guillelmo a manos de los "indios puelches viendo que el camino se había descubierto"52. La apertura del paso inquietó a los indígenas, aunque Ximena Urbina afirma que los temores eran infundados pues se habían suspendidos las malocas y que este temor se debía más bien a la resistencia indígena de que los españoles conocieran su territorio ${ }^{53}$.

Pero es el P. Mascardi el que reúne las condiciones de la muerte martirial ${ }^{54}$ o sea "el testimonio que llega al esparcimiento de la sangre por la propia fe en Dios y en Cristo" 55 , ya que no todo testimonio por la fe conlleva la entrega de la vida y la muerte sin poner resistencia alguna. Las crónicas resaltan elementos que completan esta afirmación, tales como: a) la escritura casi inmediata de su biografía $^{56}$ con la "intención de servir de inspiración para los jóvenes misioneros” ${ }^{27}$; b) su preparación y templanza física y espiritual para recibir el martirio ante la adversidad, donde la "geografía aunque muy difícil de ser enfrentada es siempre apenas un obstáculo que mas que significar un impedimento significa una forma de testimoniar la fe y resaltar las cualidades del misionero" 58 ; c) la lucha contra el demonio, tanto en el marco de la resistencia a la tentación, como en la lucha contra el mal que se consuma en la muerte martirial ${ }^{59}$ : "Mas después instigados del demonio por la guerra, que le hacia el padre, le quitaron la vida" ${ }^{60}$; d) la evocación de santos misioneros que los precedieron como modelo, que en el caso de los jesuitas del Nahuel Huapi, fue San Francisco Javier ${ }^{61}$; la predestinación divina acompañada de la libre aceptación del hombre

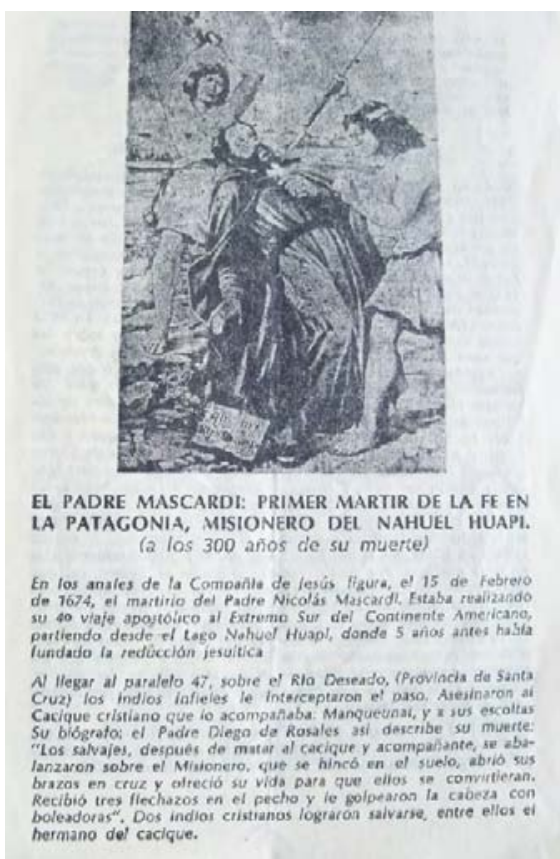

Fig. 2. Obituario del P. Mascardi. Parroquia de la Inmaculada Concepción, Bariloche 1994.

\footnotetext{
${ }^{50}$ Olivares, 1874: 196.

${ }^{51}$ Ibíd, 196.

${ }^{52}$ Ibíd, 196.

${ }^{53}$ Ibíd, 196.

${ }^{54}$ Agradezco al P. Mariano Pinasco el asesoramiento y la bibliografía sobre el tema del martirio.

${ }^{55}$ Noce, 1987: 19.

${ }^{56}$ Page, 2012: 351.

${ }^{57}$ Deckman Fleck, 2012: 10.

58 Ibid: 10.

${ }^{59}$ Noce, 1987: 19.

${ }^{60}$ Olivares, 1874: 391.

${ }^{61}$ Olivares, 1874: 191 y Enrich, 1891: 63.
} 
"hasta la muerte" ${ }^{62}$ y finalmente la muerte sufriente y violenta ${ }^{63}$.

El discurso pastoral del presente rescata a estos jesuitas, especialmente al P. Mascardi como mártires de esta Misión. En el año 1994 la Compañía de Jesús y la Parroquia de la Inmaculada Concepción de Bariloche, promovieron la causa de santidad de Mascardi por su martirio. Este obituario $^{64}$ (Fig. 2) reproduce el vitral de la Catedral (Fig. 3) ${ }^{65}$ con el relato cuya fuente principal es el jesuita Diego de Rosales, detallando su misión y su muerte en manos de los "indios infieles": "se hincó en el suelo, abrió sus brazos en cruz y ofreció su vida para que ellos se convirtieran” ${ }^{66}$.

Los elementos martiriológicos descriptos que son ilustrados por las fuentes, se observan en el caso de Mascardi: la muerte violenta: "recibió tres flechazos en el pecho y le golpearon la cabeza con boleadoras"; la predestinación a la "corona del martirio"; y el ofrecimiento voluntario de su vida: "En dicha carta prevela este desenlace y ofrecía su vida por la conversión de la raza araucana ${ }^{67}$. Este discurso actual del obituario incluye entre los

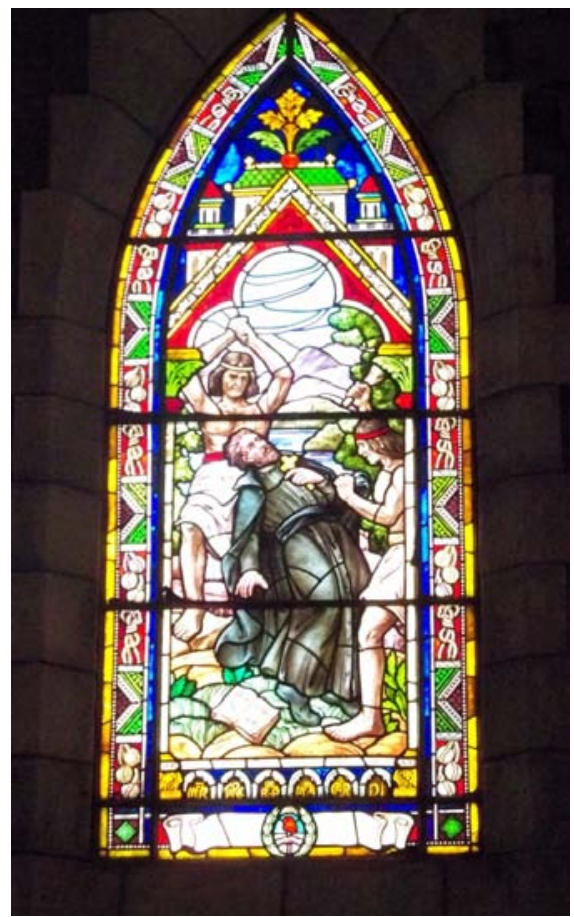

Fig. 3. Vitral del Martirio del P. Mascardi en la Catedral de Bariloche. Foto: María Andrea Nicoletti, 2013. mártires a los demás misioneros jesuitas: "El Padre de la Laguna, envenenado por el cacique Tedihue el 29 de octubre de 1707, el Padre Gaspar Sópez pereció a raíz de una tormenta de nieve en 1708, El Padre Juan José Guillelmo fue envenenado por los indios el 17 de marzo de 1716, por haber descubierto el paso secreto fue asesinado con el catequista Juan el inglés y quemado junto con la misión entera el 14 de noviembre de 1717 y finalmente el Padre Segismundo Guell fue apresado por los españoles con la ocasión de la supresión de la Compañía de Jesús el 8 de diciembre de $17677^{\prime \prime 68}$.

Hacia el año 2000, la confección de una serie de paneles en el atrio de la Catedral que narra la historia de la diócesis y la misión del Nahuel Huapi, incluye definitivamente el martirio de los otros cuatro jesuitas y tras sus nombres afirma:

\footnotetext{
62 Enrich, 1891: 53. Susini. Los textos en italiano y portugués han sido traducidos por María Andrea Nicoletti

63 Noce, 1987: 19

${ }^{64}$ Agradecemos al arqueólogo Adam Hajduk que nos facilitó este material. El Obituario reproduce en un grabado el vitral de la Catedral de Bariloche. En el obituario no se indica el autor del mismo.

${ }^{65}$ Los vitrales se realizaron con la donación de la Comisión de Damas presidida por Isabel de Nevares de Ortiz Basualdo. Los vitrales fueron confeccionados por Enrique A. Thomas, un francés radicado en Buenos Aires y se colocaron en 1947 (Vallmitjana, 1996: 5).

${ }^{66}$ Parroquia Inmaculada Concepción, Obituario de Mascardi,1994.

${ }^{67}$ Ibid.

${ }^{68}$ Ibid.
}

51 María Andrea Nicoletti. Pasado y presente: los jesuitas de la misión Nahuel Huapi... : 41-64 
“Acuérdense de sus raíces, hagan memoria de ellas, esta Iglesia particular ha sido regada en sangre martirial, hace más de 300 años”.

Este discurso que retoma el martirio, se extiende a los restantes jesuitas del Nahuel Huapi y se hace oficial en la presentación del libro del investigador local Carlos de Mendieta por el Obispo Fernando Maletti: "su sangre regó estas tierras andinas y de la estepa de la Patagonia" ${ }^{69}$, señalando De Mendieta que los misioneros "fueron verdaderos apóstoles de la fe cristiana, e irán escribiendo las páginas de esta historia una a una, manchándolas con su propia sangre" ${ }^{70}$.

El panel de la Catedral sobre los “Mártires del Nahuel Huapi”, cierra con este escrito: "Estos son los hombres que, mientras estuvieron en la tierra, plantaron la Iglesia con su sangre, recibieron el cáliz del Señor, y llegaron a ser amigos de Dios (Misa de ss Pedro-Pedro). La sangre de mártires es semilla de cristianos”.

Una misión regada por la sangre de mártires no se posiciona en la mirada de la Iglesia y de sus fieles de la misma forma que una misión, que si bien ha logrado sortear esfuerzos que pueden llegar a ser calificados en grado de heroicidad, no ha contado con la muerte violenta a causa de la fe. El libro de Carlos De Mendieta afirma que, la imagen de la Virgen de los Poyas, entronizada por Mascardi en su humilde Capilla (1672), representaría la primer presencia de la Iglesia Católica en forma permanente en nuestra Patagonia y resultaría con el correr de los siglos el testigo silencioso del sacrificio y martirio de aquellos misioneros ${ }^{71}$.

\section{La Virgen María y la Misión jesuita del Nahuel Huapi}

\section{a) La Virgen de la Misión: imágenes, advocaciones y títulos}

La Misión Nahuel Huapi fue ciertamente una misión mariana:

Esta es, Padres míos, la primera cosecha y primicias de esta cristiandad, que todas se deben al particular patrocinio y asistencia de la Virgen Santísima Nuestra Señora de Populo y ahora la llamamos Nuestra Señora de los Poyas. Y es increíble el efecto y mocíon (sic) que con su vista cría en los corazones de estos bárbaros, que apenas le ven cuando empiezan a voces a decir cada uno en su lengua: Madre mía, Madre mía limpiad mi corazón de todo pecado ${ }^{72}$.

Las fuentes que analizaremos a continuación mencionan la presencia de imágenes de la Virgen ${ }^{73}$. Según Enrich, el Virrey del Perú, Conde de Lemus, le envió en 1671 al P. Mascardi, desde El Callao a Chiloé: “doscientos ducados en plata, unas medallas del mismo metal de Nuestra Señora de los Desamparados (...), cincuenta estampas de la misma Señora, y además una bella imagen de la Purísima Virgen María, para que la colocase en la primera capilla que levantase entre los poyas. Este apreciable regalo llegó a su tiempo a manos del Padre Mascardi, que se complació con él en gran

\footnotetext{
${ }^{69}$ De Mendieta, 2010: contratapa.

${ }^{70}$ Ibid: 12.

${ }^{71}$ De Mendieta, 2010: 13.

${ }^{72}$ Mascardi, 1670: 132.

${ }^{73}$ Miguel de Olivares, Francisco Enrich (1817-1883) y el informe de Antonio Covarrubias (1718)
} 
manera, sobre todo por la bella imagen de la Purísima, que colocó en su capilla del Nahuel Huapi, tomándola por patrona de su misión"74.

En el contexto socio religioso de la época, a la Virgen Tota Pulchra, o sea "la Inmaculada Concepción, también se la llama en España Purísima Concepción y Limpia Concepción sin variación de significado” y fue objeto de una ferviente devoción popular $^{75}$.

En su Carta relación, el mismo Mascardi señala que:

“Esta es, Padres míos, la primera cosecha y primicias de esta cristiandad, que todas se deben al particular patrocinio y asistencia de la Virgen Santísima Nuestra Señora de Populo y ahora la llamamos Nuestra Señora de los Poyas. $Y$ es increíble el efecto y mocíon (sic) que con su vista cría en los corazones de estos bárbaros, que apenas le ven cuando empiezan a voces a decir cada uno en su lengua: Madre mía, Madre mía limpiad mi corazón de todo pecado" ${ }^{\text {" }}$.

En síntesis, mientras el cronista jesuita dice que la imagen entronizada en la misión Mascardi es la de una Purísima o Inmaculada Concepción (Fig. 4) ${ }^{77}$, Mascardi en su Carta Relación nos habla de una Virgen Madre "Nuestra Señora del Populo" bajo la advocación de los indígenas poyas del Lago (Fig. 5).

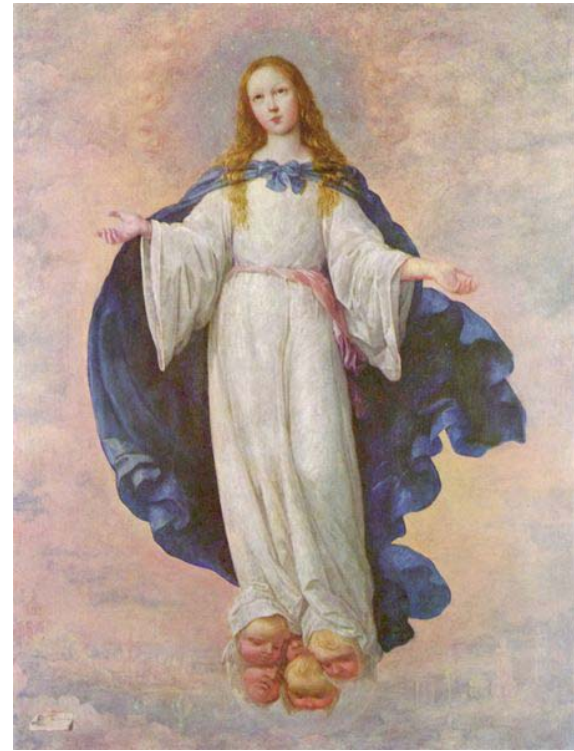

Fig. 4 Inmaculada Concepción de Zurbarán (1661). Stratton, Susanne. (1988), “La Inmaculada Concepción en el Arte español”, Revista virtual de la funda-ción universitaria española. Cuadernos de arte e iconografía, T I, $n^{\circ} 2$.

En el relato de los acontecimientos de la misión fundada por Felipe de la Laguna en 1703, Francisco Enrich escribe que: "Por este tiempo corrió entre los indios del norte y los pehuenches una epidemia de disentería; y consultados los machis respondieron ser la causa de ella una señora española, que los PP habían llevado a Nahuelhuapi para vengar la muerte del P. Mascardi. Esto decían aludiendo a una hermosa imagen de Ntra. Señora, que los PP había llevado allá pocos meses antes $(\ldots)^{78}$.

\footnotetext{
${ }^{74}$ Enrich, 1891: 742.

${ }^{75}$ Stratton, 1988: 5.

${ }^{76}$ Mascardi, 1670: 132.

77 Ilustramos la iconografía de la Inmaculada con una obra de Zurbarán de la época de la misión Mascardi. "Dos de las Inmaculadas de Zurbarán -que eran sin duda las dos últimas que pintó antes de morir en 1664- están firmadas y fechadas en 1661. Las fechas avanzadas de estas obras reflejan la importancia del año en el que la bula Sollicitudo omnium fue promulgada. En una de ellas se suprime por completo el paisaje y con él desaparecen los símbolos de las letanías. En la segunda mitad del siglo XVII, deja de sentirse la necesidad de incluir un inventario de las pruebas de la pureza virginal. Zurbarán, siguiendo probablemente el ejemplo de Morillo, renuncia a la aproximación didáctica al tema de las primeras décadas e insiste en cambio en el aspecto triunfante de la victoria de la Virgen sobre el pecado original” (Stratton,1988: Fig.76).

${ }^{78}$ El resaltado en nuestro.
} 
Inmediatamente los jesuitas les explican a los indígenas "que la Santísima Virgen no era la causa del mal sino el uso inmoderado de la chicha u otra causa natural"79. Esta cita nos habla entonces de una segunda imagen llevada por los jesuitas que fundaron la misión en Nahuel Huapi, a la que denominaron "Nuestra Señora de los pehuenches y puelches; aunque los PP decían de los puelches y poyas”80. La fuente no remite otro dato que nos permita saber si era la imagen de una Inmaculada Concepción o una Virgen María Madre. En el segundo incendio de la misión la imagen fue rescatada, según la crónica de Olivares: "la imájen de la virjen sacó uno con gran dificultad. Abrasáronse los ornamentos, libro que había mui buenos i cuanto de precioso tenía aquella misión; i por considerarla los fieles tan trabajosa i necesitada, la habían socorrido mas largamente que a ninguna otra ${ }^{81}$.

Con una prosa más rica en imágenes y con tintes epopéyicos lo mismo reproduce Francisco Enrich, agregándole al relato sobre la imagen un detalle no menor: "despojándola de sus ricos y

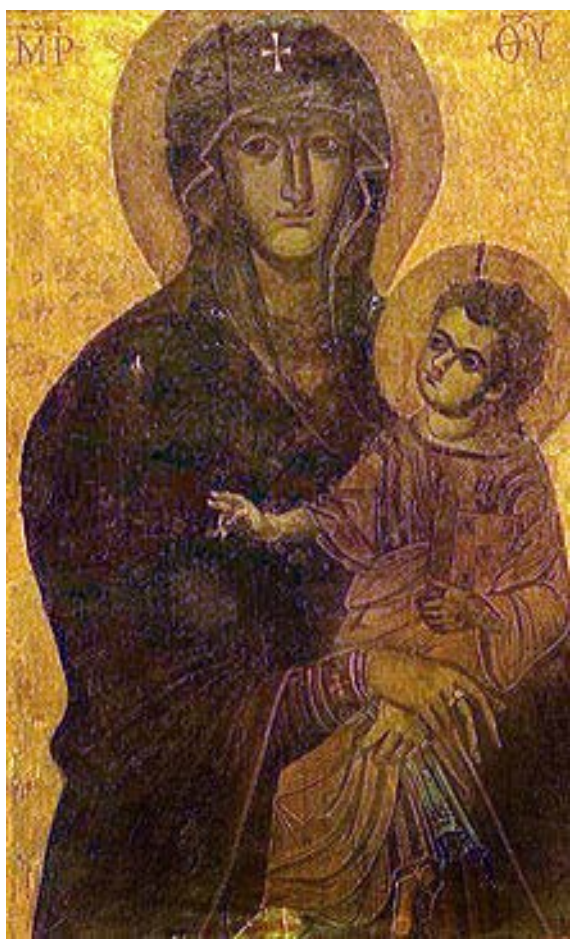

Fig. 5. Nuestra Señora del Populo (San-ta María la Mayor, Roma). Icono bizantino que representa a la Madre y el Niño.

vistosos vestidos, la dejaron cubierta con un cuero de caballo" ${ }^{82}$. Detalle que repite Olivares: "que no la hicieron sino quitarle el vestido i sacarla junto a la laguna" 83 . Fonck vuelve a reiterar que esa imagen fue cubierta en cueros y "i la colocaron junto a la orilla del lago”. En definitiva, el relato del incendio nos presenta a una imagen de vestir, traída por los jesuitas que fundaron la misión en 1703.

En relación a las advocaciones mencionadas, las fuentes se contradicen. Mascardi y Enrich coinciden en que la imagen de "Nuestra Señora de los Desamparados" se encontraba en las medallas hechas en honor de esta Virgen por el Virrey, pero la Virgen mencionada por Enrich, que es la imagen enviada a Mascardi remite a la Purísima Virgen María, que según el cronista se convierte en Patrona de la misión. Sumado a esto, la advocación que Mascardi convierte en "Nuestra Señora de la Asunción de los Poyas" es "Nuestra Señora del Populo”. El estudio de Fonck, citando a Enrich, también menciona el envío del Virrey de "medallas, estampas y una imájen de la Virjen Purísima para la capilla de Nahuelhuapi”"

En relación a la advocación es interesante destacar que Nicolás Mascardi, resignificó a "la Virgen Santísima Nuestra Señora de Populo”, como ya hemos citado,

\footnotetext{
${ }^{79}$ Enrich, 1891: 61.

${ }^{80}$ Ibíd: 55.

${ }^{81}$ Olivares, 1874: 525.

${ }^{82}$ Enrich, 1891: 100.

${ }^{83}$ Olivares, 1874: 531.

${ }^{84}$ Fonck, 1900: 38.
} 
como "Nuestra Señora de los Poyas"85. De hecho, en 1970 "llega (a Bariloche) de Roma el óleo de la Madonna del Popolo que el profesor Luis Gredda regala a la Parrroquia (Inmaculada). Fue la primera imagen venerada desde 1669 a 1671 en la Misión Jesuítica del Padre Mascardi" ${ }^{86}$, que posteriormente se menciona en las crónicas de la Parroquia Inmaculada como "Virgen de Poyas", aproximándose así a la advocación que señala directamente Mascardi en su Carta Relación: “Nuestra Señora de la Asunción de los Poyas”87.

La "Nueva misión del Nahuel Huapi" fundada en 1703 por Felipe de la Laguna, agrega a la advocación mariana de Mascardi el título de "Nuestra Señora de los Poyas y Puelches" 88 , agregando al otro pueblo de la comarca y otorgándole una resignificación identitaria mariana en torno a los pueblos que habitan la región del lago ${ }^{89}$.

Otro de los títulos marianos relacionados con la Misión es el de "Nuestra Señora del Nahuel Huapi”, que no se menciona en las fuentes coloniales. Este título evidencia una resignificación poscolonial de la etapa de los Territorios Nacionales, fruto de la construcción de la catedral, primeramente Templo mayor, de San Carlos de Bariloche en 1947, por Alejandro Bustillo. Esta advocación posiciona a la Virgen en torno al proyecto nacionalista y conservador de Bustillo de una ciudad de cara al lago y de espaldas a la población migrante mayoritariamente chilena que la constituía ${ }^{90}$.

Los paneles relacionados con la Catedral y la Historia de Bariloche reproducen un artículo de Ricardo Vallmitjana, que en su libro "La Catedral de Bariloche", aluden a localidad como una "Suiza Argentina”. Categoría que evoca el productivismo y el progreso de fines del siglo XIX y desarrollo del turismo y la organización de áreas protegidas de principios del siglo $\mathrm{XX}^{91}$.

Al llegar al Nahuel Huapi desde el viejo mundo, al ver por primera vez estas montañas, estos lagos, como no evocar a Suiza, al Tirol a Francia en sus aldeas bucólicas. Cada aldea europea, se distingue por una centenaria Iglesia que sirve de referencia (...) las viejas Iglesias de los pueblos concentran toda la fe de sus habitantes. Y todo su arte ${ }^{92}$.

Esta Iglesia fue dedicada a "Nuestra Señora del Nahuel Huapi”, “por estar situada junto al lago homónimo" (relato del atrio de la Catedral de Bariloche) y el vitral central de la Iglesia representa a la Virgen bajo esta advocación (Fig. 6). La temática de las imágenes fue un acuerdo entre Exequiel Bustillo y el entonces Obispo Essandi. Bustillo le sugirió al Obispo "tibiamente que las imágenes tuviesen vinculaciones regionales y así surgió del taller de Enrique Thomas una preciosa imagen de "Nuestra

\footnotetext{
${ }^{85}$ Mascardi, 1670: 132.

${ }^{86}$ ACDB, Crónicas de la Parroquia Inmaculada, folio 92, 26 de noviembre de 1970.

${ }^{87}$ ACDB, Crónicas de la Parroquia Inmaculada, folio 95, 8 de diciembre de 1970.

${ }^{88}$ "A la que denominaron "Nuestra Señora de los pehuenches y puelches; aunque los PP decían de los puelches y poyas” (Enrich, 1891: 55).

${ }^{89}$ Christian, 1981:154.

${ }^{90}$ Bustillo, 1999: 143.

${ }^{91}$ Navarro Floria, 2008.

${ }^{92}$ Vallmitjana, 1996: 1.
} 
Señora del Nahuel Huapi”, patrona del Templo"93, que unos turistas españoles identificaron con "Nuestra Señora de los Desamparados"94 (Fig 7). La diferencia sustancial, es la readaptación de la imagen de este vitral que conjuga el gorro frigio nacional, los rostros indígenas del Niño Jesús y de los ángeles a los pies de la Virgen, con la advocación lacustre de la "Suiza Argentina".

La Virgen del Nahuel Huapi, de advocación toponímica, se entrelaza entre el relato de un catolicismo orgánico ${ }^{95}$ y la representación de las raíces indígenas. Este discurso se transmite más claramente mediante las imágenes del vitral. Mientras el discurso sostiene una imagen mariana tradicional asociada al Bariloche del lago y su impronta nacional de la élite porteña y de inmigrantes europeos.

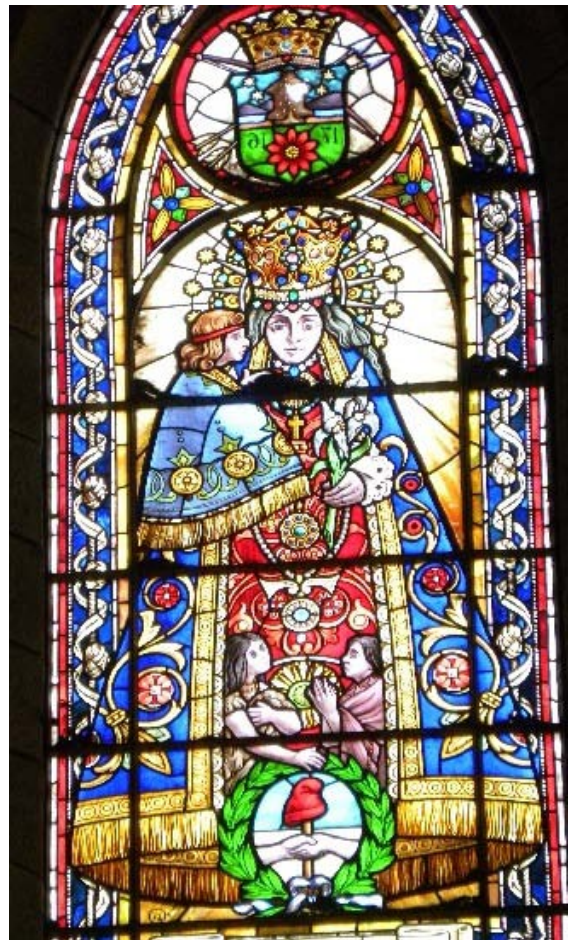

Fig. 6. Vitral de Nuestra Señora del Nahuel Huapi en la Catedral de Bariloche (Enrique A. Thomas, 1947). Foto María Andrea Nicoletti.

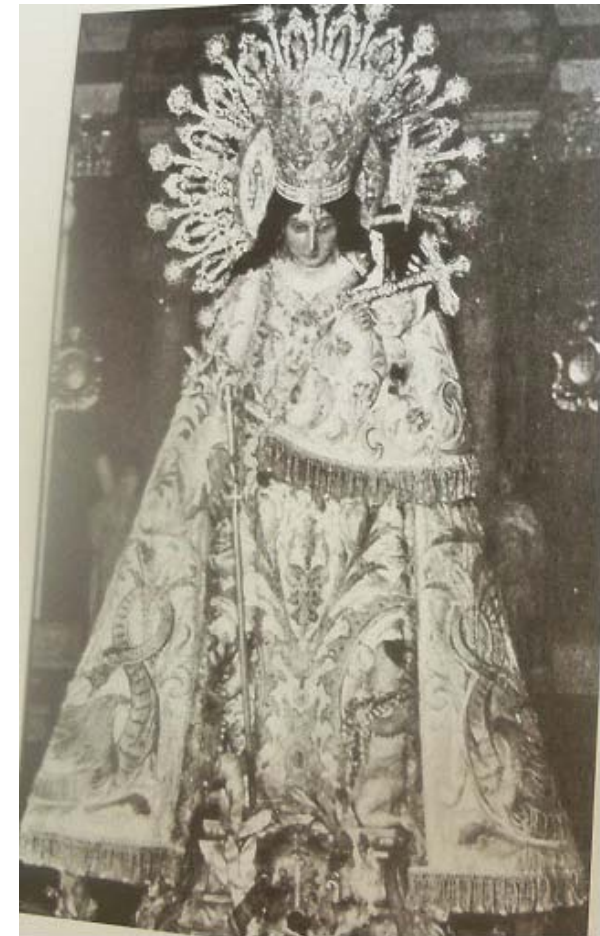

Fig. 7. Nuestra Señora de los Desamparados. Fuente: Schenone, Héctor (2008), Santa María. Iconografía del Arte colonial. Buenos Aires EDUCA: 370.

\footnotetext{
${ }^{93}$ Ibíd: 2.

94 Reportaje al Padre Pascual Bernik,Rector Mayor de la Catedral de Bariloche, por María Andrea Nicoletti e Inés Barelli, Bariloche, julio 2012. Entendemos que estos turistas españoles identifican a la Virgen como Nuestra Señora de los Desamparados de Valencia. En España esta advocación surgió en Valencia en el siglo XV para la protección de los dementes, niños inocentes, etc. (Schenone, 2008: 36972).

95 Mallimaci lo plantea como un catolicismo simbiótico entre Iglesia y Estado, cuyos militantes se identifican con lo argentino y lo patriótico como base de la identidad nacional (Mallimaci, 1992).
} 


\section{c) Pasado y presente de la imagen mariana en la Misión Nahuel Huapi}

Tras el incendio de la misión en 1717 y la muerte del P. Elguea, los jesuitas del Reino de Chile se sumaron a una expedición española para el rescate de sus restos: "De Chiloé fueron a Nahuelhuapi algunos españoles, con el P. Arnaldo Yaspers (...). El P. Yaspers vio con dolor los pocos restos de la casa e Iglesia, que el fuego no había consumido, entre los cuales halló el cuerpo quemado del P. Elguea”96.

Ximena Urbina afirma que Yaspers entró con la expedición de Uribe y Gamboa, una expedición española punitiva enviada desde Chiloé ${ }^{97}$. Esta expedición encontró “La santa imájen de la virjen junto a la laguna entre unos matorrales, cubierta con un cuero de caballo, la cual llevaron a Chiloé i de allí pasó a la Concepción”98, “en la cual fue muy venerada" 99 . Otra fuente, el informe de Antonio de Covarrubias, señala que la misión en:

“1705 fue restablecida nuevamente por los mismos regulares, bajo cuya dirección continuó hasta que el de 718 algunos naturales, enemigos de la sujeción, la saquearon, arruinaron y quemaron, dando atroz muerte a los religiosos misioneros. De resulta de esto la trasladaron a Dogell; reducción de la jurisdicción de Valdivia sobre el rio de Toten; y aunque el año de 1764 pretendieron restituirla a Nahuelhuapi; para lo cual tuvieron aprobación del superior gobierno, no llegó a tener efecto dicha pretensión, por haber sobrevenido la orden de su extrañamiento antes de concluidas las diligencias necesarias para la reposición ${ }^{\prime 100}$.

En definitiva, tras el incendio, las fuentes se contradicen sobre el paradero de los restos de la misión entre los cuales se hallaría esta imagen de la Virgen cubierta en cueros: del Nahuel Huapi a Chiloé y de allí a Concepción o bien una segunda hipótesis: de Nahuel Huapi a una reducción de Dogell en la jurisdicción de Valdivia, cómo vimos en el informe Covarruvias y porque "Nahuelhuapi dependía económicamente de aquella plaza, pero sobre todo, porque los naturales habían cortado toda comunicación entre el lago y Chiloé no quedando más vía de contacto que hacia aquella”101.

Señalamos esta cuestión pues el discurso del presente sobre el hallazgo de la imagen de la Virgen de la Misión Nahuel Huapi entronizada por Mascardi, se apoya básicamente en el periplo y destino final de la imagen buscada, rescatada del incendio de 1717, y concluye que la Virgen de la misión Nahuelhuapi es la imagen de la Virgen de Loreto de la Iglesia jesuita "Santa María de Achao”.

\footnotetext{
${ }^{96}$ Enrich, 1891: 101.

${ }^{97}$ Urbina, 2008: 26.

${ }^{98}$ Olivares, 1874: 532 y Fonck, 1900: 98.

${ }^{99}$ Enrich, 1891: 101.

${ }^{100}$ Covarrubias, 1718: 315.

${ }^{101}$ Urbina,2008: 26.
} 
En el año 2003, el diario regional Río Negro publicó la noticia del hallazgo de la Virgen que entronizó el Padre jesuita Nicolás Mascardi en 1672 en la "Misión Nahuelhuapi" (1670-1717), en la Iglesia de Achao de Chiloé. La identificación de la Virgen de la misión con la Virgen de Loreto de Achao fue certificada por dos investigadores: Carlos De Mendieta de Villa La Angostura (Neuquén) y el director del Museo Histórico de Chiloé, Renato Cárdenas ${ }^{102}$ (Fig. 8). La investigación que sostiene esta certificación fue publicada en el libro de Carlos de Mendieta "La Misión Nahuel Huapi (1670-1717) en el 2005. Una réplica de la Loreto de Achao, realizada por el escultor chilota Milton Muñoz, se trajo a la Catedral de Bariloche, donde actualmente se venera (Fig. 9).

A este supuesto hallazgo se suma una deducción controvertida y confusa. De Mendieta y Cárdenas afirman que la Virgen de la misión Mascardi, "bautizada como Nuestra Señora de la Asunción de los Poyas”, "fue recuperada luego de la destrucción de la Misión (1718) por el padre Arnold Yaspers y establecida finalmente en la Iglesia Santa María de Loreto, Achao, Chiloé, Chile". Sobre la advocación de "Nuestra Señora de Loreto" argumentan que es por ser la principal advocación mariana de los jesuitas y por tratarse de una advocación italiana como el origen de Mascardi ${ }^{103}$. El texto pasa al hallazgo de la imagen de bulto mediante una fundamentación carente de citas $^{104}$ que incurre en distintas contradicciones ${ }^{105}$. Estas se resuelven afirmando que la imagen portátil de Mascardi fue "reemplazada por la imagen de la Virgen de Loreto que le enviara el Virrey del Perú, en 1672, para entronizarla definitivamente como "Patrona de la Misión Nahuelhuapi"106.

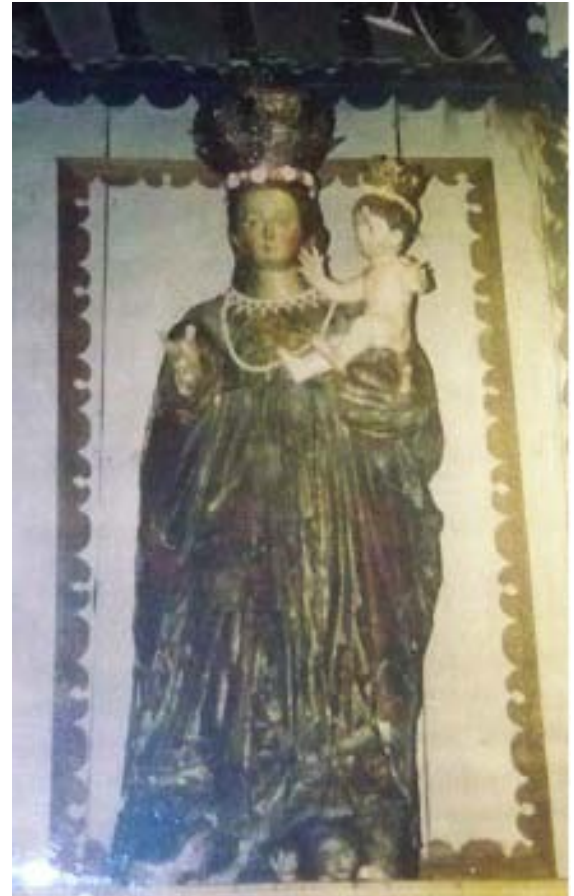

Fig. 8. Nuestra Señora de Loreto en Santa María de Achao, Chiloé, Chile. Foto situada en el Panel del Atrio de la Catedral de Bariloche que ilustra el hallazgo de la Virgen de la Misión del Nahuel Huapi.

102 Diario Río Negro, 21/2/2003.

103 De Mendieta, 2010:293.

${ }^{104}$ De Mendieta no cita los “numerosos documentos” y en un pie de página menciona el ensayo sobre Santería de Chiloé de Isidoro Vázquez de Acuña, donde identifica a esta imagen como Nuestra Señora de Loreto del Nahuelhuapi. De Mendieta, 2010: 328.

${ }^{105}$ De Mendieta afirma que la dificultad de los caminos obligaba a los jesuitas a llevar imágenes de "unos cinco o seis palmos [equivaldría a 1,00 por 1,20 metros (...) todo este cajón parado sirve de altar mayor bastante decente a los pies de la Santa Virgen” (De Mendieta, 2010: 323). Esta idea contrasta con el porte de la imagen de bulto de Loreto de Achao, a la que Mendieta identifica como la imagen de la Misión Nahuel Huapi, ya que que no es una imagen de altar portátil sino que es una imagen de mayores proporciones y ocupa uno de los nichos del Altar de la Iglesia de Santa María de Achao.

106 (De Mendieta, 2010: 293). El investigador local Vallmitjana, aporta a la investigación otra teoría, que tampoco tiene por ahora documentación contundente. En relación a la imagen cuenta que un amigo suyo, Manuel Puente, también aficionado a la historia local, "buscó en distintos archivos la historia de la Virgen y en el Archivo de Cajamarca dio con un texto del siglo XVII donde aparece citada una carta del Virrey Lemos a Mascardi en la que menciona el envió de siete imágenes de tres palmos hechas en Potosí. Valltmijana asocia la procedencia de Potosí con el material de la imagen confeccionada en plata y esta 
El hallazgo de Cárdenas y de Mendieta, tanto de la advocación de Loreto como de su rescate y traslado a Chiloé, se basa en la cita de un parte militar de la expedición del sargento mayor Martín de Uribe, a la que acompañó el jesuita Yaspers tras el incendio de la misión, citado a su vez de un texto de Abraham Silva y Molina: "penetrando diferentes riesgos, encontró la milagrosa imagen de Nuestra Señora de Loreto, que estaba escondida entre unos pellejos”107.

Sin embargo, el texto citado de Silva y Molina que encontramos en el Archivo Nacional de Chile, se denomina “Tradiciones españolas" y corresponde a la sección Fondo Varios, tomos 138 a 141 :

El año de 1718 fue nombrado capitán de cuarenta $y$ seis hombres españoles $y$ ochenta y seis indios de las reducciones de Calbuco, Abtao y Chiloé para la expedición de Nahuelhuapi, donde los indios de aquella misión habían quemado y destruido la iglesia que tenían los padres misioneros y arrojado las sagradas imágenes, y el

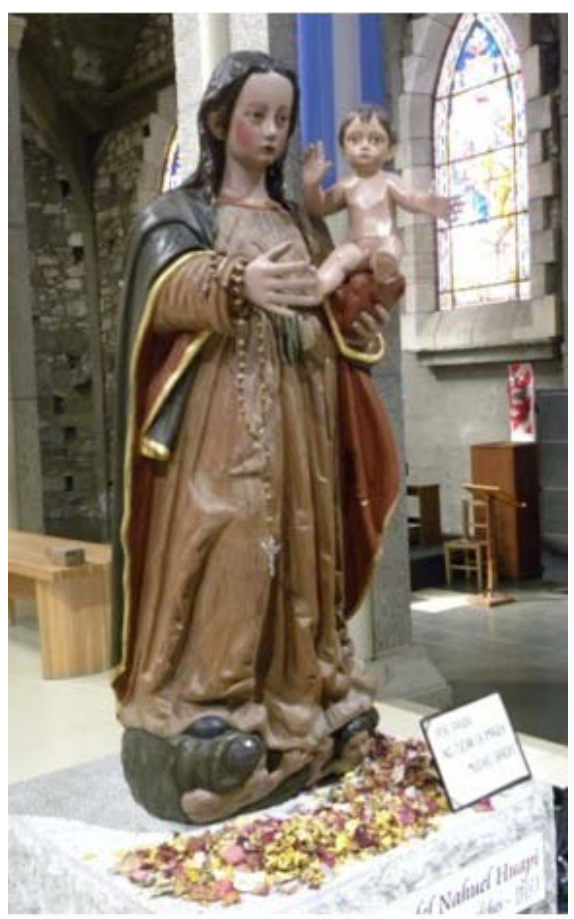

Fig. 9. Replica de Nuestra Señora de Loreto de Achao en la Catedral de Bariloche tallada por el escultor chilota Milton Muñoz. Foto. María Andrea Nicoletti, 2012. suplicante penetrando diferentes riesgo, encontró la milagrosa de Nuestra Señora de Loreto, que estaba escondida entre unos pellejos ${ }^{108}$. Y la trajo a los padres de la Compañía en una de cuyas iglesias se venera actualmente ${ }^{109}$.

En este libro manuscrito de Silva y Molina, el autor señala a la altura del texto específico, la siguiente ubicación: “Cap. Gral.vol.487”. Los documentos de Capitanía General 487 corresponden a un tomo dividido en fojas sobre encomiendas de indios de Chiloé. En este tomo, como en otros del mismo fondo documental ${ }^{110}$, aparece Martín de

idea al relato de un paisano barilochense que habría encontrado una imagen de la Virgen hecha en plata en Península San Pedro Entrevista a Ricardo Vallmitjana de María Andrea Nicoletti, Bariloche 10 de julio de 2012.

107 (De Mendieta, 2010: 293; 2005: 293-294 y 329) (Cárdenas, 2003 cit. Historia de Chiloé de Silva y Molina que cita un documento procedente del Archivo Nacional de Chile, Capitanía General, Volumen 487, IV: 61.

${ }^{108}$ Las negritas son nuestras y señalan la coincidencia de la cita que transcribe de Mendieta con la cita de Silva y Molina, para corroborar que se trata de la misma cita pero de diferente procedencia documental.

${ }^{109}$ ANCH, Fondos Varios, vol 141, foja 61. Libro manuscrito de Abraham de Silva y Molina, Tradiciones españolas de C, Santiago de Chiloé, Santiago de Chile, Imprenta que pida mas barato,1904.

${ }^{110}$ En el fondo Capitanía General de este Archivo, 515, pieza 8 fojas 150 a 157; 525, pieza 23 foja 170; 54, 526 pieza 89 foja;593; pieza 23, foja 17 y 51 pieza 8 foja 150 a 157, Martín Uribe sigue apareciendo envuelto en cuestiones de encomienda, pero hasta el momento no hemos encontrado el documento que, tal como citan Silva y Molina y posteriormente de Mendieta, lo relacionen con la expedición de rescate de Yaspers de la Virgen de la Misión bajo la advocación de Loreto y su traslado a Chiloé. Agradecemos la colaboración de la Dra. Carolina Odone y especialmente de la directora del Archivo Nacional de Chile

59 María Andrea Nicoletti. Pasado y presente: los jesuitas de la misión Nahuel Huapi... : 41-64 
Uribe o Urive en distintas fojas ${ }^{111}$ como testigo de encomiendas, pero no la cita de Silva y Molina que reproducen de Mendieta y Cárdenas.

El argumento del traslado de la imagen lo sostienen De Mendieta con el cierre de la Misión de Chequián y su transferencia a Achao "entre las cuales se encontraba una de las joyas artísticas más importantes de todo el sur del Reyno de Chile: la extraordinaria escultura de la Virgen de Loreto", otrora Virgen de los Poyas y los Puelches, ya se encontraba entronada en la Iglesia de Achao como Nuestra Señora Santa María de Achao ${ }^{112}$. De Mendieta pasa por alto la crónica del jesuita Enrich (1891), que afirma que los padres jesuitas trajeron una imagen a la nueva misión de 1703. La conclusión de De Mendieta es que si todo lo llevado por Yaspers del Nahuel Huapi a Chile fue a parar a la misión de Chequián y al cerrarse ésta todo se traslado a la Iglesia de Achao, la imagen de la Virgen de Loreto es la imagen regalada a Mascardi, sin tener en cuenta la segunda imagen que trajeron los jesuitas en 1704 con la fundación de la misión $^{113}$.

El libro de Carlos De Mendieta "La Misión Nahuelhuapi”, afirma que: "la imagen de la Virgen de los Poyas, entronizada por Mascardi en su humilde Capilla (1672), representaría la primer presencia de la Iglesia Católica en forma permanente en nuestra Patagonia y resultaría con el correr de los siglos el testigo silencioso del sacrificio y martirio de aquellos misioneros ${ }^{114}$.

Carlos De Mendieta relata la historia de la misión y asocia al asesinato y martirio del Padre Elguea a la preservación "milagrosamente intacta (de) la imagen de Nuestra Señora del Nahuel Huapi”. La presencia mariana es el punto de inflexión de esta nueva narrativa que hunde sus raíces en los mártires del Nahuel Huapi y que se equipara a otras advocaciones marianas de raíces coloniales en el territorio posteriormente argentino. Esta narrativa ya se encuentra plasmada y visible en la Catedral de Bariloche desde el 2012.

\section{Conclusiones}

La misión del Nahuel Huapi en sus dos etapas (1670-1674 y 1703-1717), constituyó una prolongación de las misiones jesuitas del Reino de Chile. El contexto de conquista de la Araucanía, espacio de una economía emergente codiciada por los españoles, estuvo envuelto en un complejo proceso bélico, producto de la resistencia indígena. La única posibilidad de aproximación de la Corona hacia ese territorio lo constituyeron las misiones jesuitas. De esta manera, el "pacto colonial” buscaba ganar

Dra. Emma Ramón que gracias a la catalogación realizada por el profesor Juan Guillermo Muñoz, me proporcionaron los datos de los documentos de este fondo donde aparece Uribe. En esta catalogación no se encuentra ningún documento que mencione a la Virgen de Loreto y sólo uno que alude al sínodo correspondiente a la reconstrucción de la Misión del Nahuel Huapi en su segundo período.

${ }^{111}$ ANCH, Capitanía General 487, Fojas 229,231, 335,337. Agradecemos a la Lic. Lic. Josefina Schenke esta búsqueda que hemos constatado posteriormente en una visita al Archivo Nacional de Chile en febrero del 2013.

112 De Mendieta, 2010: 293.

113 Enrich, 1891: 61.

${ }^{114}$ De Mendieta, 2010: 293. 
súbditos a la Corona y fieles para la Iglesia. En el siglo XVI hubo un desplazamiento de las misiones hacia Chiloé que fue centro misionero de la Compañía de Jesús en el sur de Chile.

La proyección de las misiones tras la cordillera fue el siguiente paso que se propusieron dar los jesuitas, tras las incursiones maloqueras de los esclavistas españoles. La misión de Mascardi se trató de una incursión apostólica cuyos objetivos fueron restituir a un grupo de indígenas poyas del Nahuel Huapi, esclavizados en Chiloé, reconocer el territorio trasandino, evangelizar a los grupos indígenas de la comarca del lago Nahuel Huapi y viajar hasta el Estrecho en busca de la legendaria ciudad de los Césares. Tras la muerte de Mascardi, la misión del Nahuel Huapi fue fundada por el P. de la Laguna en 1703. A pesar de los problemas de comunicación y enfrentamientos entre los grupos indígenas, la misión creció, aunque con una precaria infraestructura, con los jesuitas Guillelmo, Del Hoyo y Elguea. En 1709 la misión fue incendiada tras el descubrimiento del paso de los Vuriloche por el P. Guillelmo que fue aparentemente envenenado en 1716. La reconstrucción de la misión la realizó el P. Elguea pero fue asesinado al negarse a darles ganado a los indígenas y la misión fue saqueada e incendiada en 1717.

Hemos analizado en este trabajo dos cuestiones que advertimos en un proceso de larga duración hasta el presente: el martirio de los jesuitas de la Misión y la Virgen María en relación a sus títulos, patronazgo e imágenes. Estas dos cuestiones resultan los vectores en tensión que resignifican el discurso del presente reformulando un relato histórico en función de otorgarle profundidad e historia a la presencia de la Iglesia católica en la región. Los mártires, como "semilla de nuevos cristianos" constituyen un punto de relevancia en esta resignificación. La Virgen y el supuesto hallazgo de su imagen es la presencia silenciosa de la evangelización de los mártires.

El modelo martirial por la Fe lo cristaliza Mascardi, en quien observamos las características fundamentales del modelo martiriológico: la escritura de su vida ejemplar; la preparación y templanza física y espiritual para recibir el martirio, la lucha contra el demonio, la evocación de santos misioneros que los precedieron como modelo, la predestinación divina acompañada de la libre aceptación del hombre y finalmente la muerte sufriente y violenta. Sin embargo, las crónicas jesuitas no le otorgan el mismo status y relevancia a las muertes de los otros misioneros: de la Laguna, Guillelmo y Elguea, a las que envuelve un halo de sospecha y venganza de los indígenas. Esta apreciación se ajusta en los cronistas a la libertad en la aceptación del martirio y a las circunstancias de la muerte, por las sospechas que se ciernen sobre la intencionalidad de los asesinatos. Desde el presente, sin embargo, no sólo se reafirma el martirio de Mascardi hasta su postulación sino que el discurso visual y escrito incluyen a los jesuitas que las crónicas de la Compañía relativizan como mártires. Los vitrales de la catedral, los paneles y el discurso escrito lo refuerzan.

La narrativa martiriológica se asocia con la "imagen buscada y hallada” de la Virgen. Aquí aparece la controversia de dos discursos y dos relatos sobre el "hallazgo de la imagen”: el relato de la Bariloche lacustre del territorio nacional de Río Negro y la imagen de la Virgen del Nahuel Huapi; y el discurso de las "raíces misioneras coloniales” con la imagen de la Virgen de Loreto de Achao identificada como de los Puelches y Poyas. Las fuentes nos indican la presencia de dos imágenes distintas: la enviada por el Virrey del Perú a Mascardi y la que trajeron los jesuitas fundadores de la 
misión en 1703. En cuanto a sus títulos y advocaciones, las fuentes se contradicen. La Virgen entronizada por Mascardi, según las crónicas, es una Purísima Virgen María, pero según Mascardi en su Carta Relación es una Virgen Madre: "Nuestra Señora del Populo" a la que convierte en Patrona de la Misión con el título de "Nuestra Señora de los Poyas”. Esta misma advocación devino en "Nuestra Señora de los Poyas y Puelches” en la misión fundada por de la Laguna, pero como ya advertimos, probablemente, con una imagen portátil traída por los mismos misioneros.

Entre el período colonial y el presente, la ausencia de la imagen dio lugar a otra advocación toponímica: “Nuestra Señora del Nahuel Huapi”, fruto de la construcción de la catedral de San Carlos de Bariloche en 1947 por Alejandro Bustillo que fue representada en el vitral central de la Catedral con una iconografía semejante a "Nuestra Señora de los Desamparados”, pero con atributos indígenas y nacionales.

El derrotero de la imagen tras el incendio de la misión en 1717 también resulta en las fuentes una cuestión controvertida. Las fuentes señalan dos caminos: del Nahuel Huapi a Chiloé y de allí a Concepción o bien de Nahuel Huapi a una reducción de Dogell en la jurisdicción de Valdivia. Este camino es que el toman los investigadores locales para la búsqueda y hallazgo de la imagen de la Virgen de la misión del Nahuel Huapi a la que identifican con una imagen de bulto de leño de la Virgen de Loreto en la Iglesia jesuita "Santa María” en la isla de Achao. Una reproducción de esta imagen realizada por un escultor chilota se venera actualmente en la catedral de Bariloche.

El relato y la imagen de esta advocación particular forman un entramado discursivo en pugna. Como imagen religiosa, su supuesto hallazgo y su representación del mundo colonial poblado por aborígenes, españoles y jesuitas mártires, la posicionan como símbolo de las raíces evangelizadoras seculares en tierra de “infieles”.

\section{Referencias}

\section{Archivos}

Archivo Nacional de Chile (ANCH), Capitanía General 487, Fojas 229,231, 335,337, 515, pieza 8 fojas 150 a 157; 525, pieza 23 foja 170; 54, 525, 593,51, 526 pieza 89 foja; 593; pieza 23, foja 17 y 51 pieza 8 foja 150 a 157. Fondos varios volumen 141.

Archivo del Colegio "Don Bosco". Crónicas de la Parroquia de la Inmaculada (Bariloche).1970.

\section{Fuentes éditas}

Covarrubias, Antonio de [1718], "Memorial dirigido a la Junta de misiones". En Gay, C (1846). Documentos de la Historia física y política del Reino de Chile. T I. Paris: Maula y Renou.

De la Laguna, Felipe [1703] “Carta al Superior de la Nueva misión de la Compañía de Jesús en Sudamérica en Nahuel Huapi hacia el estrecho de Magallanes”. En Jun, 
J (trad) (1930). El Río de la Plata visto por viajeros alemanes del siglo XVIII. Revista del Instituto geográfico del Uruguay. Montevideo, nº 7, pp. 231-235.

Enrich, Francisco (1891), Historia de la Compañía de Jesús en Chile. Barcelona: Rosales.

Menéndez, Francisco (1791-92), “Diario para descubrir la Laguna de Nahuel Huapi”. En Fonk, Francisco. (1900), Viajes de Fray Francisco Menéndez. Valparaíso: Niemeyer.

Mascardi, Nicolás [1670], “Carta relación”. En Vignati,M. (1963), “Antecedentes para la protoetnografía del Norte de la Patagonia”. Boletín de la Academia Nacional de la Historia, Buenos Aires, n 34/2, pp. 495-528.

Olivares, Miguel de (1878). Historia de la Compañía de Jesús en Chile (1593-1736). Colección de Historiadores de Chile y documentos relativos a la Historia Nacional. T VII. Santiago de Chile: Mercurio.

\section{Bibliografía}

Albornoz, Ana y Hajduk, Adam (2001), "Nahuel Huapi: antecedentes arqueológicos e históricos en relación al “camino de las lagunas”, hasta el siglo XVII”. Tiempos patagónicos. Buenos Aires, n 7, pp.3-21.

Bustillo, Ezequiel (1970), El Despertar de Bariloche. Buenos Aires:Pardo.

Christian,William (1981), Religiosidad local en la España de Felipe II. London: Princeton University Press.

De Mendieta, Carlos (2010), La misión del Nahuel Huapi, 1670-1717. ViedmaBariloche: Legislatura de Río Negro.

Deckmann Fleck, Eliane (2012), "La sangre de los mártires es semilla de cristianos nuevos": a consagracao póstuma de missionários jesuitas (Provincia do paraguai, seculo XVII). En: Fogelman, P y De Luca, Candela. Actas electrónicas del IV Simposio Internacional sobre Religiosidad, Cultura y Poder. Buenos Aires: Museo Roca.

Hajduk, Adam.y Braicovich, Romina (2012) “Antecedentes históricos de la misión de los jesuitas en el Lago Nahuel Huapi. Prospecciones arqueológicas preliminares en Puerto Venado". Bariloche. (inédito).

Mallimaci, Fortunato (1992), "El Catolicismo argentino desde el liberalismo integral a la hegemonía militar”. En: AAVV: 500 años de cristianismo en Argentina. Buenos Aires: CEHILA - Centro Nueva Tierra.

Navarro Floria, Pedro. (2008), "El proceso de construcción social de la región del Nahuel Huapi en la práctica simbólica y material de Exequiel Bustillo (19341944)”. Pilquén, n 10 http://www.revistapilquen. com.ar.

Noce, Celestino (1987), Il Martirio. testimonianza e spiritualitá nei primi secoli. Roma: Edizioni Studium Roma. 
Page, Carlos (2012), Las otras reducciones jesuíticas. Emplazamiento territorial, desarrollo urbano y arquitectónico entre los siglos XVII y XVIII. Alemania: Editorial Académica española.

Schenone, Héctor (2008), Santa María. Iconografía del Arte colonial. Buenos Aires EDUCA.

Stratton, Susanne. (1988), “La Inmaculada Concepción en el Arte español”, Revista virtual de la fundación universitaria española. Cuadernos de arte e iconografía, $\mathrm{T} \mathrm{I}, \mathrm{n}^{\circ} 2$.

Susini, Mirella (2002), Il Martirio cristiano esperienza di incontro con Cristo, Bologna: EDB.

Urbina, María Ximena. (2007), “La 'puerta de Nahuelhuapi’: imaginario y formas de exploración del territorio en la frontera austral del reino de Chile”. En: Navarro Antolín, F. (Ed.) Orbis Incongnitus. Avisos y Legajos en el Nuevo Mundo. Homenaje al Profesor Luis Navarro García. Vol. I. Huelva: Publicaciones de la Universidad de Huelva.

Urbina, María Ximena. (2008), “La frustrada misión estratégica de Nahuelhuapi, un punto en la inmensidad de la Patagonia”. Magallania, Vol. 36, $\mathrm{N}^{\circ} 1$, pp. 5-30. http://www.scielo.cl/pdf/magallania/v36n1/art01.pdf

Valenzuela Márquez, Jaime. (2011), “Revisitando el “indigenismo” jesuita: en torno a los bárbaros de Arauco, la guerra y la esclavitud mapuche en el siglo XVII”. En Chamorro, G, Vieira Cavalcante, T, y Barros Goncalvez, C. (org). Fronteiras e identidades. Encontros e desencontros entre povos indígenas e missioes religiosas. XIII Jornadas Internacionais sobre as Missoes Jesuíticas. Sao Bernardo do campo: Nhanduti Editora.pp.61-80.

\section{Publicaciones periódicas locales}

Cárdenas, Renato (marzo 2003), "La Virgen de Loreto de Achao perteneció a Nahuelhuapi”. Diario del Llanquihue (Chile), marzo 2003.

Vallmitjana, Ricardo. (1996). "La catedral de Bariloche”. Revista Todo para Usted, 2,18, Bariloche.

\section{Entrevistas}

Entrevista al sacerdote Pascual Bernik por María Andrea Nicoletti e Inés Barelli, 11 de junio de 2012.

Entrevista a Ricardo Vallmitjana por María Andrea Nicoletti, Bariloche 10 de julio de 2012. 